\title{
A articulação entre ascendência e conduta como artifício retórico para louvar e vituperar os nobres nas crônicas de Gomes Eanes de Zurara
}

\section{The articulation between ascendancy and conduct as rhetorical artifice to praise and vituperate the nobles in the chronicles by Gomes Eanes de Zurara}

\section{La articulación entre ascendencia y conducta como artificio retórico para alabar y vituperar a los nobles en las crónicas de Gomes Eanes de Zurara}

iD ( Jerry Santos Guimarães

Universidade Estadual do Sudoeste da Bahia (UESB), Vitória da Conquista, Bahia, Brasil. E-mail: jerryguima@gmail.com.

\begin{abstract}
Resumo: Durante a Idade Média ibérica pensava-se que a superioridade da nobreza sobre a gente miúda residia sobretudo no sangue: os nobres, por terem "sangue elevado", estariam "naturalmente" constrangidos a buscar a honra, enquanto os plebeus, em decorrência do seu "sangue baixo", tenderiam aos vícios. Tal era a opinião e o costume do público receptor das crônicas escritas por Gomes Eanes de Zurara no século XV português. Atentando para tal fato e seguindo preceituações retóricas, Zurara articula a boa ascendência com uma conduta virtuosa ou viciosa para, respectivamente, louvar ou vituperar os nobres enquanto personagens de suas narrativas históricas.
\end{abstract}

Palavras-chave: Escrita da história - Crônicas. Gomes Eanes de Zurara - Crônicas. Literatura portuguesa - Século XV. Retórica demonstrativa. Sociedade medieval portuguesa - Nobreza. 
Abstract: During the Iberian Middle Age it was thought that the superiority of the nobles over the lower people was related mostly to blood: the nobles, because of their "elevated blood", would be "naturally" compelled to seek honor, while the plebeians, due to their "lower blood", would tend towards vices. Such was the opinion and custom of the audience of the chronicles written by Gomes Eanes de Zurara in the fifteenth century in Portugal. Observing such fact and following rhetorical precepts, Zurara articulates the good ascendancy with a virtuous or vicious conduct to, respectively, praise or vituperate the nobles as characters of their historical narratives.

Keywords: Writing of history - Chronicles. Gomes Eanes de Zurara Chronicles. Portuguese literature - Fifteenth century. Demonstrative rhetoric. Medieval Portuguese societey - Nobility.

Resumen: Durante la Edad Media ibérica se pensaba que la superioridad de la nobleza sobre la gente menuda residía sobretodo en la sangre: Ios nobles, por tener "sangre elevada", estarían "naturalmente" constreñidos a buscar la honra, mientras que los plebeyos, como consecuencia de su "sangre baja", tendrían tendencia a los vicios. Tal era la opinión y la costumbre del público receptor de las crónicas escritas por Gomes Eanes de Zurara en el siglo XV portugués. Atendiendo a tal hecho y siguiendo preceptivas retóricas, Zurara articula la buena ascendencia con una conducta virtuosa o viciosa para, respectivamente, alabar o vituperar a los nobles como personajes de sus narrativas históricas.

Palabras-clave: Escritura de la historia - Crónicas. Gomes Eanes de Zurara - Crónicas. Literatura portuguesa - Siglo XV. Retórica demostrativa. Sociedad medieval portuguesa - Nobleza.

Submetido em 14 de agosto de 2020.

Aceito em 20 de novembro de 2020.

Publicado em 21 de julho de 2021. 
A articulação entre ascendência e conduta como artifício retórico para louvar e vituperar... Jerry Santos Guimarães

Gomes Eanes de Zurara (c.1405-c.1474) prestou serviços a D. Afonso V (1432-1481), o Africano, como cronista-mor da corte régia portuguesa no terceiro quartel do século XV. Suas narrativas históricas participavam de um projeto de memória e de esquecimento que visava a enaltecer a Dinastia de Avis, de origem ilegítima, e a educar a nobreza - público primeiro das crônicas -, na medida em que fornecia uma grande quantidade de exempla a serem seguidos ou evitados (FRANÇA, 2006, p. 99, 217-219; GUIMARÃES, 2019, p. 58-196). É por isso que as crônicas zurarianas podem ser tomadas como "espelhos de nobres", na feliz expressão de André Luiz Bertoli (2009, p. 42): distintas dos famosos "espelhos de príncipes" por seu caráter narrativo, mas próximas a eles na medida em que propõem um modelo ideal a ser adotado - neste caso pela nobreza.

Mas como pintar de forma convincente as personagens das crônicas cujos comportamentos deveriam ser imitados ou repudiados? Como elogiá-las ou censurá-las de maneira adequada? Atuando durante a vigência da longa duração da instituição retórica, ${ }^{1}$ Gomes Eanes de Zurara, como qualquer cronista medieval, deveria conhecer e empregar na escrita da história determinados procedimentos técnicos com vistas a conferir verossimilhança à sua narrativa e a obter a fides do seu público. Em Portugal, ao tempo de Zurara, tais artifícios poderiam ser encontrados em autorizados tratados de arte retórica, como a Retórica a Herênio, de autor desconhecido, mas à época atribuída a Cícero, e o De Inventione, este, sim, de autoria ciceroniana (FERNANDES, 1993, p. 574-576; 2011, p. 13-32). Para o que nos interessa neste artigo cumpre destacar primeiramente como tais artes retóricas enquadram a escrita da história e, a seguir, que preceitos elas oferecem para a construção do louvor e do vitupério das personagens da ação narrada.

Marco Túlio Cícero invoca, no seu De Inventione $(1,7),{ }^{2}$ a Aristóteles, "a quien nuestro arte debe muchas contribuciones y ornamentos", para se referir aos três gêneros retóricos: o demonstrativo, utilizado para elogiar e censurar; o deliberativo, empregado

1 Sobre este assunto remetemos a Hansen (2013).

2 Utilizamos aqui a versão em espanhol La Invención Retórica, de Salvador Núñez (CICERÓN, 1997). 
A articulação entre ascendência e conduta como artifício retórico para louvar e vituperar... Jerry Santos Guimarães

para discutir questões políticas; e o judicial, ou forense, típico dos tribunais, voltado para a acusação e a defesa. O gênero demonstrativo, também chamado de epidítico, é, pois, próprio de poetas e de historiadores, ${ }^{3}$ já que ambos tanto vituperam quanto louvam os homens através de seus discursos, de acordo com o que Cícero ensina em várias de suas obras (AMBROSIO, 2005, p. 27-71). A diferença é que, segundo o que Aristóteles escreve na Poética $(9$, 1451 b), enquanto a matéria da história é o particular, ou seja, o que realmente aconteceu, a poesia trata do universal, ou do que poderia acontecer. Na definição das artes retóricas latinas anteriormente citadas, a história é um subgênero da narrativa que tem como matéria as "ações realmente empreendidas", ou os "hechos reales" (ANÔNIMO, Retórica a Herênio, I, 12-16; CICERÓN, De Inventione, I, 27).

A Retórica a Herênio (III, 10-14) preceitua que alguém pode ser louvado ou vituperado a partir: (1) das coisas externas, que são aquelas que derivam do acaso ou da fortuna; (2) das vantagens e desvantagens do seu corpo; e (3) dos vícios ou virtudes que compõem o seu ânimo. Dentre as circunstâncias externas tem importância a ascendência. No caso de o elogiado ter uma boa ascendência deve-se dizer que ele "foi semelhante ou superior" aos seus antepassados. Se, por outro lado, quer-se utilizar a boa ascendência em um vitupério, basta que se diga que a pessoa se mostrou indigna dos seus ancestrais. Cícero apresenta basicamente estas mesmas informações sobre a tríplice divisão do elogio e da censura no De Inventione (II, 177), mas acrescenta que o enunciador do discurso não deve centrar-se tanto nos aspectos corporais ou nas coisas externas, afinal seria estúpido louvar alguém por aquilo que a fortuna lhe reservou e pretensioso vituperá-lo por coisas sobre as quais não se tem controle. Daí que o melhor é levar em consideração a maneira como a pessoa usou o seu corpo e lidou com as coisas externas: se de forma virtuosa ou viciosa. No que respeita especificamente a uma boa ascendência, portanto, deve-se louvar quem dela se valeu para demonstrar vir-

\footnotetext{
3 Lembramos, contudo, que os gêneros retóricos não eram vistos como fechados em si mesmos, o que significa dizer que, embora seja classificado como partícipe do gênero demonstrativo, o discurso histórico também pode fazer e de fato faz uso do deliberativo e do judicial. Este imbricamento de gêneros, observado desde a Antiguidade, acentuou-se no decorrer da Idade Média (CURTIUS, 1957, p. 200; MALEVAL, 2010, p. 75).
} 
A articulação entre ascendência e conduta como artifício retórico para louvar e vituperar... Jerry Santos Guimarães

tudes e, por outro lado, vituperar quem, atentando contra o sangue nobre herdado dos seus antepassados, entregou-se aos vícios. É necessário, pois, que se faça uma articulação entre a ascendência e $a$ conduta, segundo Cícero.

Em assim sendo, cumpre perguntar: que expectativas havia sobre a conduta de alguém cujo sangue era considerado nobre na Idade Média ibérica? Vejamos o que escreveram algumas autoridades a este respeito.

As Siete Partidas, código jurídico escrito na segunda metade do século XIII a mando de D. Alfonso X de Leão e Castela (12211284) e que logo passou a circular em Portugal, ${ }^{4}$ recorrentemente afirmam que aquilo que é considerado nobre é também honrado $e$ limpo, encontrando-se, por conseguinte, próximo ao sagrado. Já a vileza é relacionada pelo Sábio ao pecado, ao vício e à sujidade. Ao ponderar sobre o batismo, por exemplo, "uno de los mas nobles" sacramentos da Igreja, as Siete Partidas dizem que todos os que o recebem devem se ter por honrados e limpos porque através dele se achegam a Deus, "que es la cosa mas noble et mas honrada que podria ser en el mundo" (ALFONSO X, Partida Primera, tít. IV, lei 18). O pecado, por outro lado, "es por natura vil et sucio", e o homem que a ele se entrega não tem parte "en la nobleza nin en la limpiedumbre de Dios", já que prefere ter como senhor o Diabo, "que es siervo, et vil et despreciado mas que otra criatura" (ALFONSO $X$, Partida Primera, tít. IV, lei 18).

Ainda tratando de assuntos eminentemente religiosos, as Siete Partidas estabelecem que as igrejas não devem ser erigidas nos locais vis das vilas, ou seja, próximo ao bairro das prostitutas, dos açougues ou de depósitos de lixo. E se algum templo viesse a ser abandonado, as suas pedras e madeira poderiam ser reutilizadas apenas na construção de uma nova igreja ou de um hospital para pobres, mas nunca "en lugar vil, asi como establia ó cocina, ó en otro lugar semeiante destos", quer dizer, onde houvesse ou se produzisse sujeira (ALFONSO X, Partida Primera, tít. X, lei 8).

4 Ainda no século XIII as Siete Partidas foram traduzidas para o português, e há evidências de sua aplicação em Portugal já na centúria seguinte (SILVA, 1985, p. 161). 
A articulação entre ascendência e conduta como artifício retórico para louvar e vituperar... Jerry Santos Guimarães

Também o sangue dos homens poderia ser classificado como "nobre" e "limpo", estando, portanto, associado à honra, ou "baixo" e "sujo", atrelando-se deste modo à vileza. Desde os primórdios do reino português já se pensava que a superioridade dos nobres em relação ao povo comum poderia ser explicada, dentre outros motivos, devido à superioridade do seu sangue. De acordo com José Mattoso, a preeminência da nobreza senhorial não supunha necessariamente o exercício de uma autoridade delegada pelo rei, mas sim e principalmente a transmissão dos poderes via sangue dos pais para os filhos. Tal ideia se faz presente nos primeiros termos utilizados para designar a nobreza em Portugal. A palavra infanções, por exemplo, usada nos séculos XI e XII, etimologicamente aponta para a noção de jovens aparentados com os chefes militares e, por extensão, para a sua função bélica - outro fator de superioridade dos nobres sobre o povo. A expressão coeva filii benenatorum, bem mais utilizada pelos notários portugueses de então, traz de forma inequívoca a ligação entre a condição social e um bom nascimento. E é precisamente neste sentido que tal expressão antecede a designação fidalgos - filhos-de-algo - cujo primeiro registro conhecido em Portugal data do começo do século XIII. A honra e a vileza, deste modo, segundo o pensamento da época, eram herdadas pelo sangue e transmissíveis aos descendentes: ou se era filho de alguém, ou se era filho de um qualquer do povo (MATTOSO, 1985, p. 101-113).

As Ordenações Afonsinas, promulgadas em Portugal em meados do século $X V$, determinam que só podem ser considerados fidalgos os nobres "que venham de direita linha de padre, e de madre, e d'avoo ataa quarto graao, a que chamam visavoos", todos eles nobres (liv. I, tít. LXIII, § 8). Quem não fosse filho, neto e bisneto de nobres por todos os seus costados, portanto, não poderia declarar-se fidalgo. Este princípio foi bebido das Siete Partidas, no mesmo passo em que o Sábio prescreve que o nobre de linhagem deve guardar a sua fidalguia como se guarda uma herança, cuidando para que aquilo que teve início nos ascendentes e foi por eles acrescentado no decorrer das gerações não diminua e nem se 
A articulação entre ascendência e conduta como artifício retórico para louvar e vituperar... Jerry Santos Guimarães

acabe (ALFONSO X, Partida Segunda, tít. XXI, lei 2). Em vista disto, não deve o sangue fidalgo misturar-se com o sangue vilão através do casamento: "porque el mayor denuesto que la cosa honrada puede haber es cuando se mezcla [...] con la vil" (ALFONSO X, Partida Segunda, tít. XXI, lei 3). Como se pensava que a honra era transmitida pelo pai, D. Alfonso $X$ ensina que um filho de um fidalgo com uma vilã é também em sentido estrito fidalgo, mas atenção: não é nobre. Se, por outro lado, o filho nasce de um vilão com uma fidalga, ele nem é fidalgo, nem é nobre (ALFONSO X, Partida Segunda, tít. XXI, lei 3).

Através das Siete Partidas ficamos a saber ainda que no século XIII ibérico havia um grupo social que, em honra e em sangue, era inferior à nobreza: a "gente menuda", composta por "menestrales et labradores" (ALFONSO X, Partida Segunda, tít. X, lei 1). Também em Portugal no século XV os mesteirais, ou oficiais mecânicos, juntamente com lavradores e serviçais em geral, compunham a chusma da "gente miúda", ou "povo miúdo" (GUIMARÃES, 2019, p. 197-287). Como eles se sujavam ao trabalharem com as mãos, não poderiam ser considerados nem "limpos", nem "honrados" (GODINHO, 1971, p. 63, 83-84). Um dos motivos pelos quais os "vis" mesteirais não deveriam fazer parte da cavalaria, a propósito, é porque, não possuindo sangue nobre, eles estariam desprovidos de vergonha, que é o que afinal impede "ao Cavalleiro fogir da batalha" e "o faz seer vencedor", segundo o que se pode ler nas Ordenações Afonsinas. Não estando sujeito ao constrangimento da vergonha imposto pelo sangue elevado, o peão é "ligeiro pera fugir" (liv. I, tít. LXIII, §§ 4-5).

A natureza do sangue, portanto, impele a que se busque a honra ou o seu contrário. O princípio vem da Antiguidade: Aristóteles já havia escrito que as virtudes de um nobre "são inerentes à sua estirpe", uma vez que "a nobreza é uma dignidade transmitida pelos antepassados" (ARISTÓTELES, Retórica, II, 15, 1390b). É possível, porém, ainda segundo o Estagirita, que muitos nobres de boa linhagem não consigam preservar as suas "qualidades naturais". Estes que decaem e degeneram podem até ser nobres de sangue, 
A articulação entre ascendência e conduta como artifício retórico para louvar e vituperar... Jerry Santos Guimarães

mas são de "vil carácter" (ARISTÓTELES, Retórica, II, 15, 1390b). E é justamente por isso que o escritor catalão Ramon Llull (1235c.1315) estabelece que, para que alguém seja aceito na ordem da cavalaria, não basta que tenha sangue nobre, mas deve ter também um "coração nobre", o que é perceptível na demonstração de virtudes. Daí que um fidalgo de "coração vil", por mais alto que seja o seu sangue, nunca deveria ser armado cavaleiro (LLULL, Libro de la Orden de Caballería, I, 8; III, 1-10). O próprio Zurara, a propósito, em sua Crónica de Guiné (1973, p. 365), ${ }^{5}$ diz que um "nobre coração" é reconhecível pela busca da honra através da realização de nobres feitos. E, na Crónica da Tomada de Ceuta (1992, p. 56), ${ }^{6}$ ele escreve que embora o conde de Barcelos "falecesse na nobreza da geração quanto à parte da madre", 7 por suas virtudes e "grandeza de coração" ele "escondia a baixeza do sangue" materno.

Deste modo, a relação opositiva nobre / sangue alto / honra / virtude X vilão / sangue baixo / vileza / vício era uma regra que comportava exceções. Esperava-se que uma boa ascendência constrangesse o afortunado às virtudes, mas sabia-se que o sangue per se não poderia garantir uma vida honrosa. Assim, ao tratar dos nobres em suas narrativas históricas, Zurara elogia ou censura tais personagens de acordo com a conduta demonstrada em relação à sua boa ascendência: o nobre virtuoso, por agir consoante o seu sangue, merece louvor; já o nobre que incorre em vícios, mostrando-se indigno dos seus ancestrais e rebaixando-se ao nível da gente miúda, é duramente repreendido.

A virtude cardeal mais utilizada por Zurara para louvar os nobres nas suas crônicas é a fortaleza, segundo constatou Miguel Aguiar (2018). Tal virtude abarca o que chamamos hoje de "coragem", palavra que no século XV ainda não havia sido incorporada à língua portuguesa. Além de "fortaleza", utilizava-se também a palavra "ardideza" para designar a capacidade de enfrentar o medo

\footnotetext{
5 Concluída oficialmente em 1453, de acordo com o seu explicit, mas com evidentes acréscimos posteriores, nesta crônica Zurara narra a expansão marítima portuguesa pelas ilhas atlânticas e pela costa ocidental africana até a altura da Senegâmbia, num período cronológico que vai de 1434 a 1448.

6 Também chamada de Terceira Parte da Crónica de D. João I, a Crónica da Tomada de Ceuta foi concluída por Zurara em 1450, segundo se pode ler no seu explicit. Sua matéria principal é a conquista de Ceuta, no Marrocos, pelos portugueses em 1415. 70 denominado conde de Barcelos trata-se de D. Afonso (1377-1461), que depois foi o $1^{\circ}$. duque de Bragança, filho bastardo do rei D. João I com uma Inês Pires, dona de origem incerta (COELHO, 2005, p. 17-18).
} 
A articulação entre ascendência e conduta como artifício retórico para louvar e vituperar... Jerry Santos Guimarães

da morte no campo de batalha (AGUIAR, 2016, p. 60; MONTEIRO, 1998, p. 474). Na Crónica do Conde D. Pedro de Meneses, ${ }^{8}$ no discurso que o cronista atribui a D. João I (1357-1433) momentos antes do seu retorno vitorioso de Ceuta para Portugal, o rei encoraja os "capitães e gemte nobre que ally aviã de ficar" com as seguintes palavras: "aymda que quyssesseys, nõ poderiais fazer o comtrario do que comvosco naçeo dos vemtres de vossas madres, que foy ardimemto e fortalleza" (ZURARA, 1997, p. 205, grifo nosso). Tendo eles herdado sangue nobre, portanto, estavam "naturalmente" constrangidos a não temer, segundo Zurara. Páginas adiante lemos que mesmo alguns nobres que se mostraram temerosos de permanecer em Ceuta estavam ao menos cientes de que tinham uma vontade "natural" de se defenderem "per força de [seu] samgue" (ZURARA, 1997, p. 212).

A diferença na qualidade dos sangues da gente miúda e da nobreza pode ser percebida na narração que Zurara faz de uma escaramuça entre nobres portugueses e "mouros de pee". O cronista escreve o seguinte sobre o confronto "rrosto per rrosto", quer dizer, direto, entre o cavaleiro-fidalgo Martim Lopes de Azevedo e um peão mouro: "e a fim se veo a combater cõ aquelle fidallgo, o quall lhe fez semtir aquello que os nobres homẽs tem de melhoria sobre a gemte que a natureza nõ proveo de melhor samgue" (ZURARA, 1997, p. 376-377, grifo nosso). Não se trata aqui meramente de uma distinção qualitativa entre os sangues de um cristão e de um infiel, segundo o topos nação, mas especialmente entre o sangue de um fidalgo e o de um peão. Afinal, como veremos adiante, até mesmo os mouros nobres são louvados pelo cronista quando agem em conformidade com o seu "alto sangue".

No capítulo em que dá notícia da morte do cavaleiro-fidalgo Fernão Barreto, Zurara o louva porque "assy como hera nobre no samgue, assy avia nobres comdições e costumes" (ZURARA, 1997, p. 404). Fernão Barreto pôde ser elogiado, portanto, porque o seu modo de vida mostrou-se até o fim condizente com a qualidade do sangue herdado dos seus ascendentes.

$\overline{8 \text { Escrita entre } 1458 \text { e }} 1464$, nesta obra Zurara narra a manutenção e a defesa de Ceuta desde a sua tomada pelos portugueses, em 1415, até a morte do seu primeiro capitão-fronteiro, o conde D. Pedro de Meneses (1370-1437). 
A articulação entre ascendência e conduta como artifício retórico para louvar e vituperar... Jerry Santos Guimarães

Com o objetivo de combater corsários de Castela que causavam problemas ao abastecimento de Ceuta, D. João I enviou para o Estreito de Gibraltar alguns navios sob a capitania de D. Fernando de Noronha, fidalgo de altíssimo quilate, uma vez que ele era neto de reis..$^{9}$ Eis as palavras de Zurara a respeito da condição dos homens que foram naquela frota: "E nõ pemsees que ally hera gemte plebea nem comũ, mas toda gemte cortesam de bõ samgue e criaçõ" (ZURARA, 1997, p. 550-551). Do irmão deste D. Fernando, D. Sancho de Noronha, ${ }^{10}$ Zurara diz que, no que respeita a matar infiéis, "tamto seu samgue hera mais nobre que os outros, tamto se esforçava mais pera o fazer" (ZURARA, 1997, p. 692-693). Este elogio a D. Sancho de Noronha é repetido na última obra zurariana, a Crónica do Conde D. Duarte de Meneses (ZURARA, 1978, p. 91). ${ }^{11}$

Gomes Eanes de Zurara enaltece a D. Afonso de Vasconcelos como o melhor fidalgo que saiu do reino em socorro a Alcácer Ceguer durante um dos cercos que esta vila marroquina, já então sob o domínio português, sofreu, e o motivo é que ele tinha "grandeza de linhagem" e, consequentemente, "bondade de costumes". ${ }^{12}$ Destacou-se o dito D. Afonso de Vasconcelos em um rebate que os cristãos fizeram contra os mouros durante o assédio, e o motivo, explica Zurara, estava na alteza do seu sangue:

E que todos muyto bem fizessem nom se contentaua aquelle nobre Senhor dom Affomso de ser contado com os comunaaes. mas assy como era o mais nobre em sangue e uallor que ally andaua. assy se quis stremar na excellencya dos feitos assy ardidamente cometya os Jmijgos assy os leuaua ante sy. que caasy spantados sguardauam em elle ueendosse uencidos de tam pequena forma. (ZURARA, 1978, p. 206-207, grifo nosso).

\footnotetext{
9 Este fidalgo era filho do castelhano D. Afonso Henriques, conde de Noronha, filho natural do rei D. Enrique II de Castela (13341379), e de D. Isabel, filha natural do rei D. Fernando de Portugal (1345-1383). Por ser casado com D. Brites, condessa de Vila Real e filha do conde D. Pedro de Meneses, D. Fernando de Noronha tornou-se o $2^{\circ}$. conde de Vila Real. Após a morte do sogro assumiu a capitania e o governo de Ceuta. Zurara tencionava escrever uma crônica sobre os seus feitos (ZURARA, 1997, p. 183; 1978, p. 55).

10 Atuou como fronteiro-mor de D. Afonso V no Alentejo e em 1449 tornou-se o $1^{\circ}$ conde de Odemira. Como o seu irmão, foi capitão e governador de Ceuta. D. Sancho de Noronha foi ainda agraciado com a comenda-mor da Ordem de Santiago pelo infante D. Fernando (1433-1470), irmão de D. Afonso V (GOMES, 2009, p. 91, 230, 241).

11 Escrita entre 1464 e 1468, esta crônica narra a tomada de Alcácer Ceguer, no Marrocos, pelas hostes de D. Afonso V, em 1458 , bem como os primeiros anos de sua manutenção e defesa sob a capitania do conde D. Duarte de Meneses (1414-1464). 120 cronista qualifica a este fidalgo ainda como "magnyfico" (ZURARA, 1978, p. 234). D. Afonso de Vasconcelos foi agraciado por D. Afonso V em 1471 com o recém-criado condado de Penela. Foi também senhor de Soalhães e Campores (CRUZ, 1995, p. 210).
} 
A articulação entre ascendência e conduta como artifício retórico para louvar e vituperar... Jerry Santos Guimarães

Como se pode perceber, a excelência das obras deste fidalgo era um reflexo, segundo o cronista, da excelência do seu sangue - sangue este que o afastava em qualidade não apenas dos "comunais", isto é, dos homens do terceiro estado, ${ }^{13}$ mas até mesmo de todos os outros nobres presentes naquela escaramuça.

É perceptível o entusiasmo de Zurara ao narrar combates em que participava a nobreza de sangue mais elevado. $\mathrm{O}$ cronista escreve que o conde D. Pedro de Meneses mandou aparelhar suas quatro fustas mormente com "gemte espiçiall" para fazer o resgate de Fernão da Silva, escudeiro-fidalgo do então infante D. Duarte (1391-1438) que se encontrava sob o poder dos infiéis. Ora, aqueles nobres cristãos acabaram se deparando no mar com fustas de mouros em que também havia "muita mais e melhor gemte que as outras", seguindo-se daí uma batalha naval. Como os guerreiros em sua maioria, tanto cristãos quanto mouros, eram de altíssimo sangue, deu-se, nas palavras do cronista, "hũa muy fera e aspera pelleja, tamto mayor quamto d'amballas partes a gemte herã mais nobres" (ZURARA, 1997, p. 623-627).

Isto explica via contraste a grande desmotivação que, segundo Zurara, se abateu sobre os escudeiros de D. Henrique (1394-1460) quando a frota portuguesa partiu no verão de 1415 para tomar Ceuta: pareceu-lhes algo contra a razão o fato de este infante e $o$ seu pai, o rei D. João I, quererem investir sobre a poderosa cidade marroquina com combatentes cuja "maior parte [era] da gente miúda". Isto soou àqueles escudeiros, de acordo com o que o cronista escreve em sua obra de estreia, como uma desculpa antecipada para o provável fracasso da expedição (ZURARA, 1992, p. 211).

Afinal, como vimos páginas atrás ao citar as Ordenações Afonsinas (liv. I, tít. LXIII, §§ 4-5), amedrontar-se e fugir dos inimigos era uma conduta típica da peonagem: não possuindo sangue nobre, os guerreiros da gente miúda geralmente não tinham vergonha de debandar. Outras autoridades confirmam o topos do peão covarde.

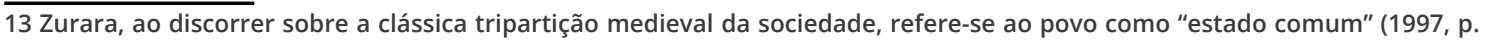
176-177). 
A articulação entre ascendência e conduta como artifício retórico para louvar e vituperar... Jerry Santos Guimarães

Em seu Compêndio da Arte Militar (III, 12, 22), Flávio Vegécio, escritor latino do século IV muito apreciado na Idade Média ibérica, ${ }^{14}$ aconselha o chefe da hoste a posicionar os cavaleiros diante da infantaria, uma vez que os inimigos poderiam ficar mais confiantes com a visão dos peões fugindo. $E$, de acordo com D. Alfonso X de Leão e Castela, o capitão, ao lidar com os medrosos guerreiros das "gentes menudas et de poco esfuerzo", deve encorajá-los assim como o médico faz com o paciente que pensa que vai morrer (ALFONSO $X$, Partida Segunda, tít. XXIIII, lei 22). A atualização do topos do peão covarde, a propósito, é com frequência utilizada por Gomes Eanes de Zurara para vituperar os combatentes das camadas baixas do povo nas suas crônicas (GUIMARÃES, 2019, p. 337-356). O vício da covardia era algo, pois, que a nobreza cristã a serviço do rei português no norte africano deveria evitar, tanto por constrangimento do seu alto sangue quanto pelo fato de que eles eram os guerreiros mais bem equipados e armados (MONTEIRO, 1998, p. 474).

As coisas nem sempre se davam assim, contudo. Gonçalo VeIho, por exemplo, cavaleiro e comendador da Ordem de Cristo, ao verificar que alguns dos nobres que eram com ele se amedrontaram diante dos inimigos e tencionavam fugir, repreendeu-os por agirem como "gemte fraca, ẽ que nõ há nenhũa esperamça de ffee nẽ de virtude", segundo Zurara (1997, p. 570). Aquele nobre teve mesmo de ameaçar os seus companheiros de castigo físico para que não debandassem: “E por ẽ, costramgidos mais de temor que da vergonha, ouveram-se de rreteer" (ZURARA, 1997, p. 570). Não quis Gonçalo Velho, contudo, valer-se apenas da ameaça para convencê-los a permanecer nos seus postos e a lutar. $O$ fidalgo apelou também para um outro argumento:

Pois tornemos ally amtre aquelles vallados, omde poderemos comprar nossas mortes como homẽes em que há verdadeira ffee cristã e nobreza de corações. Oo! que vitupério seria vos outros, que tamtas vezes pellejastes ẽ maar e em terra, averdes assy villãmemte d'acabar vossos derradeiros dias! (ZURARA, 1997, p. 570-571, grifo nosso).

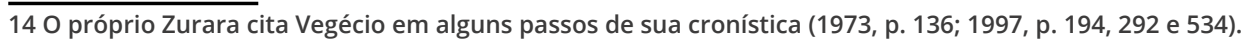


A articulação entre ascendência e conduta como artifício retórico para louvar e vituperar... Jerry Santos Guimarães

O cronista, portanto, através do discurso que atribui a Gonçalo Velho, diz obliquamente que só pode louvar os nobres que respeitam o seu sangue e agem de forma honrosa - com "nobreza de coração". Aos escudeiros, cavaleiros e fidalgos que, a despeito de suas linhagens, se comportam como os covardes vilãos, só caberia o vitupério.

Era mais expectável que a conduta de um nobre mouro fosse mais honrosa do que a de um peão cristão. Aquele, afinal, tinha sangue elevado nas suas veias. A respeito de dois filhos de Salah ibn Salah, ex-alcaide de Ceuta, por exemplo, Zurara escreve que "assy como vijnham de nobre sangue. assy eram homens de grandes anymos deseiadores de obrar grandes feitos" (ZURARA, 1978, p. 262). Se num capítulo Zurara vitupera a "gemte rrustica e popullar" dos mouros por se entregar mesquinhamente ao roubo de "pequena presa", no seguinte o cronista louva um nobre daqueles infiéis porque, combatendo, "fez ally sua fim, não por çerto como homẽ villão nẽ que havia o coraçom fraco nẽ femenill, porque todas suas feridas foram por diamte, e jaa Ihe a força de todo desfalleçia, jazemdo no chão e aynda com tenemça de comtemder pera os comtrairos" (ZURARA, 1997, p. 362-367, grifo nosso). Morrera, pois, honradamente, lutando até o fim, como convinha a um membro da nobreza.

Uma das formas de insultar a alguém de nobre linhagem consistia em acusar a tal pessoa de, a despeito do seu sangue superior, agir como um vilão. Encontramos tal precedente em Fernão Lopes (138?-c.1460), antecessor de Zurara no cargo de cronista-mor da corte régia portuguesa e, portanto, uma das principais autoridades para o nosso cronista. ${ }^{15}$ Lopes escreve que, pouco antes da chegada de D. Juan I de Castela (1358-1390) para montar o seu cerco sobre Lisboa, em 1384, saíram da cidade homens de alta condição, como Fernão Pereira, irmão do condestável D. Nuno Álvares Pereira, o doutor Martim Afonso, que depois foi bispo de Braga, e João Lourenço da Cunha, nobre de quem a rainha D. Leonor Teles

15 Nomeado oficialmente cronista pelo rei D. Duarte em 1434, Fernão Lopes já vinha escrevendo crônicas sobre os reis portugueses. Antecedeu a Zurara também enquanto guarda-mor da Torre do Tombo. É provável que, antes de suceder a Lopes, Zurara tenha trabalhado sob a sua supervisão durante algum tempo na secretaria régia (FRANÇA, 2006, p. 110). 
A articulação entre ascendência e conduta como artifício retórico para louvar e vituperar... Jerry Santos Guimarães

fora esposa antes de se casar com D. Fernando, acompanhados de outros "mui boõs homẽes darmas", isto é, nobres, ${ }^{16}$ além de besteiros e homens de pé. Ao vê-los, o rei castelhano tratou a todos com desdém, como se fossem da mesma condição social. Eis as palavras que Lopes atribui a D. Juan I, dirigindo-se aos de sua companhia: "Vos outros nom veedes, como estes villaãos andam fora da çidade sem rreçeo nehuũ que de nos ajam? A elles, a elles, fazellos emçarrar dentro, caar villaãos som todos" (LOPES, 1983, p. 217, grifo nosso). Atrevidos, por certo, mas ainda assim equivalentes a vilãos e, portanto, vis e facilmente derrotáveis, segundo a perspectiva do rei castelhano construída por Fernão Lopes.

Vejamos agora alguns exemplos zurarianos de insultos a nobres acusados de agirem como vilãos. Escreve o nosso cronista que D. Duarte de Meneses, visando encorajar os seus homens numa escaramuça com os mouros, desqualificou a todos os seus contrários, aí incluídos os seus nobres e mesmo os xeques, dizendo que com pouco esforço dos cristãos eles fugiriam pelos matos, à guisa da gente miúda: "todo he uillanagem" (ZURARA, 1978, p. 195, grifo nosso). E já no fim do segundo cerco de Alcácer Ceguer, numa troca de ofensas via correspondência com Albofacem Bonatuz, marim, ou "regedor", do rei de Fez, o capitão português acusou o nobre mouro de ter agido com "royndade e grande vileza" por covardemente não ter aceitado o seu desafio para um duelo; ao ter ofendido a D. Duarte de Meneses como "perro", ${ }^{17}$ o marim ainda se comportara "descortesmente" (ZURARA, 1978, p. 231-232, grifo nosso). ${ }^{18}$

Nestes passos fica evidente que para Zurara os nobres, independentemente da sua nação, são "naturalmente" constrangidos pelo seu sangue a buscar honra; já os miúdos do povo, o seu contrário. O nobre mouro que fere o decoro da sua condição incorre,

\footnotetext{
16 O sentido forte da expressão “homens de armas", bem como “gentes de armas”, segundo Maria Ângela Beirante (1984, p. 55), é o de "nobres bem armados que combatem a cavalo constituindo a cavalaria pesada, o que não obsta a que possam combater a pé".

170 termo "perro" integra os "topoi do insulto" identificados por João Adolfo Hansen (2004, p. 360). Tal ofensa é utilizada na narrativa zurariana tanto da parte de cristãos contra mouros $(1992$, p. 201,$216 ; 1973$, p. 165; 1978, p. 232) quanto de mouros contra cristãos $(1978$, p. 127, 230-231).

18 O cronista Rui de Pina (1440-1522) também faz referência a esta troca de cartas entre o marim e D. Duarte de Meneses e, assim como Zurara, assevera que o nobre mouro usou de "pallavras de grande descortesia, e muyta villeza" (PINA, 1977, p. 789, grifo nosso).
} 
A articulação entre ascendência e conduta como artifício retórico para louvar e vituperar... Jerry Santos Guimarães

pois, em vilanagem / vilania / vileza, termos estes intercambiáveis na pena zurariana. E o mesmo princípio vale obviamente para os nobres cristãos.

A cupidez desmedida por riquezas materiais era considerada um vício típico de vilãos na Idade Média ibérica. D. Alfonso X, ao discorrer sobre os movimentos das peças no tabuleiro de xadrez, esclarece que a possibilidade de o peão saltar duas casas para a frente no primeiro lance mimetiza o comportamento dos peões na guerra: "esto es a semeiança que quando el pueblo menudo roban algunas cosas" (ALFONSO X, Libro de Axedreç, Dados e Tablas, p. 5, grifo nosso). Nos deslocamentos seguintes o peão do xadrez só pode avançar uma casa a cada jogada, numa referência ao seu homônimo no campo de batalha, o qual, carregando às costas tudo o que pôde roubar, torna-se a partir de então mais lento (ALFONSO $\mathrm{X}$, Libro de Axedreç, Dados e Tablas, p. 5). Era verossímil, pois, que os soldados do povo miúdo, vistos como "naturalmente" propensos à cobiça exagerada, se adiantassem às hostes e saltassem sobre os bens dos inimigos, pilhando desordenadamente (HANSEN; MOREIRA, 2013, p. 255). Agindo assim os peões colocavam-se a si próprios e a todos os seus companheiros em risco, uma vez que, segundo Flávio Vegécio, os combatentes costumam se distrair enquanto saqueiam, tornando-se assim vulneráveis a um contra-ataque surpresa (Compêndio da Arte Militar, III, 11). Este era um problema constante para os chefes militares portugueses. Afinal, como argumenta o infante D. João (1400-1442) em conselho escrito a seu irmão, o rei D. Duarte, a única coisa que movia "Besteyros Pyões" a irem voluntariamente para a guerra era a ganância pelo que poderiam roubar (DOM JOÃO, 1433 apud DUARTE, 1982, p. 44).

Esperava-se dos nobres, por outro lado, que não cobiçassem senão a honra de vencer os seus inimigos. Em consonância com tal princípio e tentando evitar os efeitos danosos provocados pelo saque antes de terminado um confronto militar, tanto as Siete Partidas (Partida Segunda, tít. XXVI, prólogo e lei 2) quanto as Ordenações Afonsinas (liv. I, tít. LI, § 33) determinam que a pilhagem dos bens dos adversários só deve ter lugar após a vitória 
A articulação entre ascendência e conduta como artifício retórico para louvar e vituperar... Jerry Santos Guimarães

estar assegurada. É só então que o nobre, em recompensa pela honra demonstrada no campo de batalha, pode auferir o seu justo proveito (DUARTE, 2015, p. 185). Em assim sendo, se Zurara recorrentemente censura os guerreiros da gente miúda devido à sua cobiça desmesurada pelo roubo durante uma peleja, ${ }^{19}$ não poupará os nobres que, num afrontoso desrespeito ao seu sangue, apresentam uma conduta semelhante.

De dois inominados nobres que se lançaram ao roubo antes de terminada uma escaramuça com os mouros, Zurara diz que se "acabaram villmemte" (1997, p. 342-343, grifo nosso). Situação similar fora narrada páginas antes, quando o cronista contou como cinco escudeiros de Ceuta, com "mais semtido no ganho que esperavão que na homrra e seguramça da vida", imprudentemente apearam e começaram a se apossar dos pertences dos inimigos mortos. Em tal descuido aqueles nobres cristãos foram apanhados por outros mouros, ao que se seguiu uma vergonhosa morte (ZURARA, 1997, p. 300-301).

Zurara nos conta ainda que no ano de 1430 duas galés de Castela foram bem recebidas pelos portugueses em Ceuta: uma tinha por patrão a Gonçalo de Cuadros e a outra a Afonso d'Eça. Segundo a narrativa zurariana, um dia estes nobres castelhanos fingiram partir da cidade, mas na verdade passaram a noite no mar, à espreita. Sendo já "oras de comer", avistaram alguns portugueses "acarretamdo lenha com carros", quer dizer, viram em terra firme homens da gente miúda executando o seu costumeiro trabalho braçal. Gonçalo de Cuadros ordenou então a um dos seus que os fosse filhar, porém sem sucesso, já que aqueles peões conseguiram escapar. O castelhano não desistiu do seu propósito e conseguiu apreender um barco com pescado e alguns homens do já citado D. Fernando de Noronha. Aproximando-se novamente da terra, Gonçalo de Cuadros tentou seduzir outros homens da gente miúda portuguesa que serviam em Ceuta alegando que ali onde estavam parecia que viviam em cativeiro. Além disso - continuou o fidalgo castelhano -, certamente eles deveriam estar enfadados

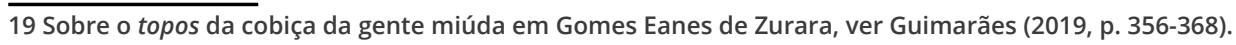


A articulação entre ascendência e conduta como artifício retórico para louvar e vituperar... Jerry Santos Guimarães

"de comer milho e beber vinagre". O melhor que eles poderiam fazer seria, pois, ir embora consigo para Castela. Depois de dar graças a Deus, ao rei de Portugal e ao conde D. Pedro de Meneses e de negar que se alimentassem com viandas tão mesquinhas, um daqueles peões passou a censurar o comportamento de Gonçalo de Cuadros. Eis as suas palavras, segundo a pena zurariana:

E vos, pois sois fidallgo e vos temdes em comta de gemtill-homẽ, nõ obrastes como devies. Caa leyxo sermos cristãos e termos firmeza de pazes amtre nos, mas que foram ymfies, nõ obrarais de tall vilania filhamdo a gemte, sobre tamto gasalhado como rreçebestes do comde [D. Pedro de Meneses] e de cuamtos bõos fidallgos aquy sõ, o que nõ sey parte do mundo em que homẽs aja que tenhã rrezão que nõ ajam por mall o que fezestes, se aymda acomteçera a hũ cossario villão, fora menos cullpa, mas tais homẽs com nomes de fidallgos, nõ sey que nobreza podeys ter quamdo aquy tam mall obrastes. (ZURARA, 1997, p. 642-643, grifo nosso).

Temos aqui, pois, um vilão acusando um fidalgo de vilania, o que confere maior eloquência ao discurso construído por Zurara. O que o nobre queria obrar não era típico de alguém de sua condição social e nem de seu sangue fidalgo, mas era coisa de vilãos, uma vez que Gonçalo de Cuadros estava a priorizar o ganho que teria com os cativos e pouco se importava com o fato de que eles fossem seus irmãos de fé numa terra de infiéis. Aparentemente envergonhado com a repreensão feita por um peão, o nobre castelhano "quysera escusar-se, peroo sua escusa trazia pouca onestidade" (ZURARA, 1997, p. 643). Continuava o fidalgo e gentil-homem, pois, a agir com vileza, a despeito do seu alto sangue.

Quaisquer danos materiais que homens de uma nação cristã provocassem sobre membros de outra nação igualmente cristã, estando ambas de pazes firmadas, poderiam ser tomados como vilania, segundo Zurara, já que isto se constituía, conforme assinalamos, numa anteposição do proveito à honra. O cronista nos conta que no dia 11 de janeiro de 1462 chegou a Alcácer Ceguer 
A articulação entre ascendência e conduta como artifício retórico para louvar e vituperar... Jerry Santos Guimarães

o nobre Álvaro Dias, ${ }^{20}$ o qual informou a D. Duarte de Meneses que um tal de João Galego havia tomado um navio que ia de Mértola carregado de pão para abastecer aquela praça. Ao saber de tal notícia, D. Duarte de Meneses encolerizou-se profundamente, uma vez que sua vila estava "muy fallecida de mantijmento". Daí as suas palavras de desprezo em relação ao dito João Galego: "ca mayor despeito tenho deste villaão que se mo fezerom mouros. ca quando nos este faz guerra que he christãao nom sey quem nolla nom faça" (ZURARA, 1978, p. 281-282, grifo nosso). Uma vez mais, portanto, a ideia do dano provocado por um cristão estrangeiro sobre cristãos portugueses é associada à imagem do vilão. Gonçalo de Cuadros, já o vimos, era fidalgo, daí que a vilania que Zurara Ihe atribui afigura-se como um insulto: agira como um "cossario villão". Já o corsário João Galego, ao que parece, era de fato vilão, condição social esta que na boca do enfurecido conde D. Duarte de Meneses ganha um sentido de desprezo ainda mais forte. ${ }^{21}$

Ter uma boa ascendência, portanto, não era suficiente para garantir o elogio do cronista de D. Afonso V. Apenas os nobres que demonstrassem virtudes, notadamente a fortaleza, mereciam de fato ter os seus nomes e os seus feitos louvados eternamente através da escrita autorizada da história. Descender de uma linhagem nobre, afinal, não era uma escolha do indivíduo, mas um acaso da fortuna, como destacou Cícero. Esperava-se, pois, que o nobre de sangue fosse também, nas palavras de Aristóteles, "nobre de carácter", e nas palavras de Ramon Llull e do próprio Zurara, "nobre de coração". Caso contrário, o nobre de "coração vil", em que pese a sua boa ascendência, não poderia esperar da pena do cronista outra coisa senão repreensão - às vezes posta até mesmo na boca de um reles peão, para maior vergonha daquele que não se mostrou digno dos seus ancestres.

\footnotetext{
20 Zurara nomeia-o entre os "fidalgos e nobres homeens" que foram de Ceuta a Alcácer Ceguer tão logo souberam do primeiro cerco mouro a esta vila. Diz ainda o cronista que Álvaro Dias era copeiro do infante D. Fernando (ZURARA, 1978, p. 129). 21 Álvaro Dias e o conde D. Duarte de Meneses estavam equivocados com respeito aos propósitos do dito João Galego. Dando prosseguimento à sua história, Zurara informa que a caravela de João Galego havia filhado um barco da Galiza carregado de peixe seco e, quando já voltava com a sua presa, fora por sua vez filhado por uma galé da Provença. Foi sobre estas três embarcações que investiu o jovem D. Henrique de Meneses, filho do capitão de Alcácer Ceguer, acompanhado de 30 fidalgos e gentis-homens, naquela que é a mais dura batalha naval descrita por Zurara, segundo ele próprio assevera. Foi uma peleja entre a fidalguia portuguesa que servia em Alcácer Ceguer e corsários franceses referidos com desprezo pelo cronista como "quatro ladroões" e "tam uil gente" (ZURARA, 1978, p. 281-291). Para uma análise deste confronto narrado por Zurara, remetemos a Luís Miguel Duarte (2017, p. 243-253).
} 
A articulação entre ascendência e conduta como artifício retórico para louvar e vituperar... Jerry Santos Guimarães

\section{Referências}

AGUIAR, Miguel. As crónicas de Zurara: a corte, a aristocracia e a ideologia cavaleiresca em Portugal no século XV. Medievalista, Lisboa, n. 2, jan.-jun. 2018. Disponível em: https://doi.org/10.4000/ medievalista.1580. Acesso em: 4 dez. 2020.

AGUIAR, Miguel. Ideologia cavaleiresca em Portugal no século XV. 2016. 148 f. Dissertação (Mestrado em Estudos Medievais) - Faculdade de Letras, Universidade do Porto, Porto, 2016. Disponível em: https:// www.academia.edu/26653912/Ideologia_Cavaleiresca_em_Portugal_ no_S\%C3\%A9culo_XV. Acesso em: 4 dez. 2020.

ALFONSO X (Don). Libro de axedreç, dados e tablas. P. SánchezPrieto, Rocío Díaz Moreno, Elena Trujillo Belso: Edición de textos alfonsíes en REAL ACADEMIA ESPAÑOLA: Banco de datos (CORDE). Corpus diacrónico del español. Disponível em: https://ebuah.uah.es/dspace/ bitstream/handle/10017/7295/Libro\%20ajedrez.pdf. Acesso em: 14 ago. 2020.

ALFONSO X (Don). Las siete partidas del rey D. Alfonso el Sabio, cotejadas con varios códices antiguos por la Real Academia de la Historia. t. I. Partida Primera. Madrid: Imprenta Real, 1807. Disponível em: http://www.cervantesvirtual.com/obra-visor/las-siete-partidas-del-rey-don-alfonso-el-sabio-cotejadas-con-varios-codices-antiguos-por-la-real-academia-de-la-historia-tomo-1-partida-primera--0/html/. Acesso em: 14 ago. 2020.

ALFONSO X (Don). Las siete partidas del rey D. Alfonso el Sabio, cotejadas con varios códices antiguos por la Real Academia de la Historia. t. II. Partida Segunda y Tercera. Madrid: Imprenta Real, 1807. Disponível em: http://www.cervantesvirtual.com/obra-visor/las-siete-partidas-del-rey-don-alfonso-el-sabio-cotejadas-con-varios-codices-antiguos-por-la-real-academia-de-la-historia-tomo-2-partida-segunda-y-tercera--0/html/. Acesso em: 14 ago. 2020.

AMBROSIO, Renato. De rationibus exordiendi: os princípios da história em Roma. São Paulo: Associação Editorial Humanitas / Fapesp, 2005. 
A articulação entre ascendência e conduta como artifício retórico para louvar e vituperar... Jerry Santos Guimarães

ANÔNIMO. Retórica a Herênio. Tradução e introdução de Ana Paula Celestino Faria e Adriana Seabra. São Paulo: Hedra, 2005.

ARISTÓTELES. Poética. 3. ed. Prefácio de Maria Helena da Rocha Pereira. Tradução e notas de Ana Maria Valente. Lisboa: Fundação Calouste Gulbenkian, 2008.

ARISTÓTELES. Retórica. Tradução e notas de Manuel Alexandre Jr., Paulo Farnhouse Alberto e Abel do Nascimento Pena. Lisboa: Imprensa Nacional / Casa da Moeda, 1998.

BEIRANTE, Maria Ângela. As estruturas sociais em Fernão Lopes. Lisboa: Livros Horizonte, 1984.

BERTOLI, André Luiz. O cronista e o cruzado: a revivescência do ideal de cavalaria no outono da Idade Média portuguesa (século XV). 2009. 175 f. Dissertação (Mestrado em História) - Setor de Ciências Humanas, Letras e Artes, Universidade Federal do Paraná, Curitiba, 2009.

Disponível em: https://www.academia.edu/19287457/O_Cronista_e_o_ Cruzado_A_Revivesc\%C3\%AAncia_do_Ideal_da_Cavalaria_no_Outono_ da_Idade_M\%C3\%A9dia_Portuguesa_S\%C3\%A9culo_XV. Acesso em: 4 dez. 2020.

CICERÓN. La invención retórica. Introducción, traducción y notas de Salvador Núñez. Madrid: Editorial Gredos, 1997.

COELHO, Maria Helena da Cruz. D. João I: o que re-colheu Boa Memória. Lisboa: Círculo de Leitores, 2005.

CRUZ, Abel dos Santos. A nobreza portuguesa no Marrocos no século XV: (1415-1464). 1995. 325 f. Dissertação (Mestrado em História Medieval) - Faculdade de Letras, Universidade do Porto, Porto, 1995. Disponível em: https://repositorio-aberto.up.pt/handle/10216/27423. Acesso em: 4 dez. 2020.

CURTIUS, Ernst Robert. Literatura européia e Idade Média latina. Tradução de Teodoro Cabral e Paulo Rónai. Rio de Janeiro: Ministério da Educação e Cultura / Instituto Nacional do Livro, 1957.

DUARTE, Luís Miguel. A caravela contra a galé. Memórias 2016, Lisboa, v. XLVI, p. 243-253, 2017. Disponível em: https://academia.marinha.pt/ 
A articulação entre ascendência e conduta como artifício retórico para louvar e vituperar... Jerry Santos Guimarães

pt/academiademarinha/Edies/Memorias_2016.pdf. Acesso em: 4 dez. 2020.

DUARTE, Luís Miguel. Ceuta, 1415: 600 anos depois. Lisboa: Livros Horizonte, 2015.

DUARTE (Dom). Livro dos conselhos de el-rei D. Duarte (Livro da Cartuxa). Edição diplomática de João José Alves Dias. Revisão de A. H. de Oliveira Marques e Teresa F. Rodrigues. Lisboa: Editorial Estampa, 1982.

FERNANDES, R. M. Rosado. Breve introdução aos estudos retóricos em Portugal. In: LAUSBERG, Heinrich. Elementos de retórica literária. 6. ed. Tradução, prefácio e aditamentos de R. M. Rosado Fernandes. Lisboa: Fundação Calouste Gulbenkian, 2011. p. 13-32.

FERNANDES, R. M. Rosado. Retórica. In: LANCIANI, Giulia \& TAVANI, Giuseppe (org. e coord.). Dicionário da literatura medieval galega e portuguesa. 2. ed. Tradução de José Colaço Barreiros e Artur Guerra. Lisboa: Editorial Caminho, 1993. p. 574-576.

FRANÇA, Susani Silveira Lemos. Os reinos dos cronistas medievais (Século XV). São Paulo: Annablume; Brasília: Capes, 2006.

GODINHO, Vitorino Magalhães. A estrutura da antiga sociedade portuguesa. Lisboa: Editora Arcádia, 1971.

GOMES, Saul António. D. Afonso V: o Africano. Lisboa: Círculo de Leitores / Temas e Debates, 2009.

GUIMARÃES, Jerry Santos. “De qualquer outro do povo escrevera seu feito, se o achava em merecimento": memória e esquecimento da "gente miúda" nas crônicas de Gomes Eanes de Zurara. 527 f. Tese (Doutorado em Memória: Linguagem e Sociedade) - Programa de Pós-Graduação em Memória: Linguagem e Sociedade, Universidade Estadual do Sudoeste da Bahia, Vitória da Conquista, 2019. Disponível em: https://www.academia.edu/43037191/_De_qualquer_outro_do_povo_escrevera_seu_feito_se_o_achava_em_merecimento_ Mem\%C3\%B3ria_e_esquecimento_da_gente_mi\%C3\%BAda_nas_cr\%C3\%B4nicas_de_Gomes_Eanes_de_Zurara. Acesso: 4 dez. 2020. 
A articulação entre ascendência e conduta como artifício retórico para louvar e vituperar... Jerry Santos Guimarães

HANSEN, João Adolfo. Instituição retórica, técnica retórica, discurso.

Matraga, Rio de Janeiro, v. 20, n. 33, p. 11-46, jul.-dez. 2013. Disponível em: https://www.e-publicacoes.uerj.br/index.php/matraga/article/ view/19759/14255. Acesso em: 4 dez. 2020.

HANSEN, João Adolfo. A sátira e o engenho: Gregório de Matos e a Bahia no século XVII. 2. ed. São Paulo: Ateliê Editorial; Campinas: Editora da UNICAMP, 2004.

HANSEN, João Adolfo; MOREIRA, Marcello. Para que todos entendais: poesia atribuída a Gregório de Matos e Guerra: letrados, manuscritura, retórica, autoria, obra e público na Bahia dos séculos XVII e XVIII. v. 5. Belo Horizonte: Autêntica, 2013.

LOPES, Fernão. Crónica de D. João I. v. I. Com uma introdução de Humberto Baquero Moreno e um prefácio de António Sérgio. Porto: Livraria Civilização Editora, 1983.

LLULL, Ramon. Libro de la orden de caballería. Traducción de Luis Alberto de Cuenca. Madrid: Alianza Editorial, 1986.

MALEVAL, Maria do Amparo Tavares. Fernão Lopes e a retórica medieval. Niterói: Editora da Universidade Federal Fluminense, 2010. MATTOSO, José. Identificação de um país: ensaio sobre as origens de Portugal. 1096-1325. v. I. Oposição. Lisboa: Editorial Estampa, 1985.

MONTEIRO, João Gouveia. A guerra em Portugal nos finais da Idade Média. Lisboa: Editorial Notícias, 1998.

ORDENAÇÕES Afonsinas. Reprodução "fac-símile" da edição da Real Imprensa da Universidade de Coimbra, 1792. Lisboa: Fundação Calouste Gulbenkian. 5 v. Disponível em: http://www1.ci.uc.pt/ihti/proj/ afonsinas/. Acesso em: 14 ago. 2020.

PINA, Rui de. Chronica do senhor rey D. Affonso V. In: PINA, Rui de. Crónicas de Rui de Pina. Introdução e revisão de M. Lopes de Almeida. Porto: Lello \& Irmão Editores, 1977. p. 576-881.

SILVA, Nuno J. Espinosa Gomes da. História do direito português: fontes de direito. Lisboa: Fundação Calouste Gulbenkianl, 1985. 
A articulação entre ascendência e conduta como artifício retórico para louvar e vituperar... Jerry Santos Guimarães

VEGÉCIO, Flávio. Compêndio da arte militar. Tradução de João Gouveia Monteiro e José Eduardo Braga. Coimbra: Imprensa da Universidade de Coimbra, 2009.

ZURARA, Gomes Eanes de. Crónica da tomada de Ceuta. Introdução e notas de Reis Brasil. Lisboa: Publicações Europa-América, 1992.

ZURARA, Gomes Eanes de. Crónica de Guiné. 2. ed. Introdução, novas anotações e glossário de José de Bragança. Barcelos: Livraria Civilização Editora, 1973.

ZURARA, Gomes Eanes de. Crónica do conde D. Duarte de Meneses. Edição diplomática de Larry King. Lisboa: Universidade Nova de Lisboa, 1978.

ZURARA, Gomes Eanes de. Crónica do conde D. Pedro de Meneses. Edição e estudo de Maria Teresa Brocardo. Braga: Fundação Calouste Gulbenkian / Junta Nacional de Investigação Científica e Tecnológica, 1997. 